\title{
Antimicrobial peptides properties beyond growth inhibition and bacterial killing
}

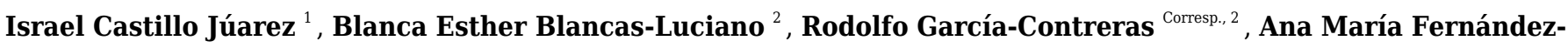 \\ Presas ${ }^{\text {Corresp. } 2}$ \\ 1 Laboratorio de Fitoquímica, Posgrado de Botánica, Colegio de Postgraduados, Texcoco, Estado de México, Mexico \\ 2 Departamento de Microbiología y Parasitología, Facultad de Medicina, Universidad Nacional Autónoma de México, Mexico City, Mexico City, Mexico \\ Corresponding Authors: Rodolfo García-Contreras, Ana María Fernández- Presas \\ Email address: rgarc@bq.unam.mx, presas@unam.mx
}

Antimicrobial peptides (AMPs) are versatile molecules with broad antimicrobial activity produced by representatives of the three domains of life. Also, there are derivatives of AMPs and artificial short peptides that can inhibit microbial growth. Beyond killing microbes, AMPs at grow sub-inhibitory concentrations also exhibit anti-virulence activity against critical pathogenic bacteria, including ESKAPE pathogens. Anti-virulence therapies are an alternative to antibiotics since they do not directly affect viability and growth, and they are considered less likely to generate resistance. Bacterial biofilms significantly increase antibiotic resistance and are linked to establishing chronic infections. Various AMPs can kill biofilm cells and eradicate infections in animal models. However, some can inhibit biofilm formation and promote dispersal at sub-growth inhibitory concentrations. These examples are discussed here, along with those of peptides that inhibit the expression of traits controlled by quorum sensing, such as the production of exoproteases, phenazines, surfactants, toxins, among others. In addition, specific targets that are determinants of virulence include secretion systems (type II, III, and VI) responsible for releasing effector proteins toxic to eukaryotic cells. This review summarizes the current knowledge on the anti-virulence properties of AMPs and the future directions of their research. 


\section{Antimicrobial peptides properties beyond growth 2 inhibition and bacterial killing}

3

4

5

6

7

8

8

9

10

12

13

14

15

16

17

18

19

20

21

22

23

24

25

26

27

28

29

30

31

32

33

34

35

36

37

5
Israel Castillo-Juárez ${ }^{1}$, Blanca Esther Blancas-Luciano ${ }^{2}$, Rodolfo García-Contreras ${ }^{2 *}$, Ana

María Fernández-Presas 2*

${ }^{1}$ Laboratorio de Fitoquímica, Posgrado de Botánica, Colegio de Postgraduados, Texcoco, Mexico.

${ }^{2}$ Departamento de Microbiología y Parasitología, Facultad de Medicina, UNAM, Mexico City.

Corresponding Authors:

Rodolfo García-Contreras ${ }^{2}$

Av. Universidad 3000, Col. Universidad Nacional Autónoma de México, CP 04510, Mexico

City, Mexico.

Email address: rgarc@bq.unam.mx

Ana María Fernández-Presas ${ }^{2}$

Av. Universidad 3000, Col. Universidad Nacional Autónoma de México, CP 04510, Mexico City, Mexico.

Email address: presas@,unam.mx 
39

40

41

42

43

44

45

46

47

48

49

50

51

52

53

54

55

56

57

58

59

60

61

62

63

64

65

66

67

68

69

\section{Abstract}

Antimicrobial peptides (AMPs) are versatile molecules with broad antimicrobial activity produced by representatives of the three domains of life. Also, there are derivatives of AMPs and artificial short peptides that can inhibit microbial growth. Beyond killing microbes, AMPs at grow subinhibitory concentrations also exhibit anti-virulence activity against critical pathogenic bacteria, including ESKAPE pathogens. Anti-virulence therapies are an alternative to antibiotics since they do not directly affect viability and growth, and they are considered less likely to generate resistance. Bacterial biofilms significantly increase antibiotic resistance and are linked to establishing chronic infections. Various AMPs can kill biofilm cells and eradicate infections in animal models. However, some can inhibit biofilm formation and promote dispersal at sub-growth inhibitory concentrations. These examples are discussed here, along with those of peptides that inhibit the expression of traits controlled by quorum sensing, such as the production of exoproteases, phenazines, surfactants, toxins, among others. In addition, specific targets that are determinants of virulence include secretion systems (type II, III, and VI) responsible for releasing effector proteins toxic to eukaryotic cells. This review summarizes the current knowledge on the anti-virulence properties of AMPs and the future directions of their research.

\section{Introduction}

The discovery of antibiotics is one of the most important events in modern medicine. The scientific community interest and the pharmaceutical industry for their commercialization in the mid-20th century favored the so-called golden age of these molecules (Díaz-Nuñez, García-Contreras \& Castillo-Juárez, 2021). However, the generation of resistance of microorganisms to bactericides is a global public health problem and represents one of the critical challenges to be solved by humanity (Muñoz-Cazares et al., 2017). Therefore, new targets or mechanisms of action are being investigated, in which antimicrobial peptides (AMPs) are an option to combat drug-resistant infections (Boparai \& Sharma, 2019; Lei et al., 2019; Magana et al., 2020).

67 Most living organisms produce antimicrobial peptides as a defense mechanism in eukaryotes or as

8 a microenvironmental competition strategy in prokaryotes (Moretta et al., 2021). Around 17,363 AMPs have been described, in which $82.7 \%$ are synthetic, and the rest are produced naturally in 
70 the three domains of life (Bulet, Stöcklin \& Menin, 2004; Boparai \& Sharma, 2019; Zasloff, 2019).

71 They are classified according to their source of origin, activity, structure, and amino acid 72 composition (Huan et al., 2020). Most AMPs are monomers of 4 to 50 amino acids that can acquire 73 an amphipathic secondary structure of $\alpha$-helix, $\beta$-hairpin-like $\beta$-sheet, $\beta$-sheet, or $\alpha$-helix/ $\beta$-sheet 74 mixed structures (Bulet, Stöcklin \& Menin, 2004).

75

76

77

78

79

80

81

82

83

84

85

86

87

88

89

90

91

92

93

94

95

96

97

98

99

In mammals, AMPs are a fundamental part of the innate immune system to counteract microbial infections (Boman, 2000). Some, such as defensins, are produced by epithelial cells to prevent the establishment of pathogens and are generally found in phagocytic cells to help eliminate microorganisms when ingested (Bulet, Stöcklin \& Menin, 2004; de la Fuente-Núñez et al., 2017).

In plants, AMPs are produced in different tissues to protect against pathogens; specifically, thionins and snakins are the best known (Tang et al., 2018). Bacteriocins are AMPs produced by bacteria, which have been identified as having a high antimicrobial activity (Soltani et al., 2021), while in archaea, halocins and sulfolobicins are the two main classes of archaeocins, which meet several ecological functions of competition in the environment with extreme conditions (Besse et al., 2015).

6

Classical antimicrobial properties are the main characteristic described for AMPs, and they are active against a broad spectrum of microorganisms, including viruses and parasites (Harris, Dennison \& Phoenix, 2009; Huan et al., 2020). The primary mechanism reported for AMPs is related to their ability to lyse microbial cells (Pasupuleti, Schmidtchen \& Malmsten, 2012; Mankoci et al., 2019) since the cationic properties (net positive charge) of most of them allows them to interact with the membranes of microorganisms (Alghalayini et al., 2019) (Figure 1). However, other action mechanisms have also been described in which AMPs interact directly with specific target molecules (Brogden, 2005; Le, Fang \& Sekaran, 2017; Graf \& Wilson, 2019). Some of them have similar action mechanisms to antibiotics, including the inhibition of protein synthesis (pleurocidin and indolein) (Subbalakshmi \& Sitaram, 1998; Patrzykat et al., 2002), or cell wall synthesis (mersacidin) (Brötz et al., 1998). Others, such as temporin L and the synthetic peptide 35409 (RYRRKKKMKKALQYIKLLKE), inhibit Escherichia coli divisome machinery (BarretoSantamaría et al., 2016; Di Somma et al., 2020). Unfortunately, because AMPs affect the viability 
100 of microorganisms, resistance mechanisms towards them are also reported (Cassone et al., 2009;

101 Haney, Straus \& Hancock, 2019).

102

103 In addition, AMPs influence several other biological processes (Haney, Straus \& Hancock, 2019);

104 for example they interfere with the regulation of the microbiota, wound healing, induction of 105 adaptive immunity, as well as possess anti-inflammatory, pro-inflammatory, anti-cancer, and 106 cytotoxic properties, among others (Beisswenger \& Bals, 2005; Haney, Straus \& Hancock, 2019; 107 Huan et al., 2020). Thus, due to its multifunctional nature, some authors have begun to use the 108 broader term "host defense peptide" (HDP) (Haney, Straus \& Hancock, 2019).

109

Anti-virulence activity is the antimicrobial property that has been discovered in various molecules when used at growth sub-inhibitory concentrations, in which they block the ability of bacteria to cause damage without interfering with their viability (Castillo-Juarez et al., 2017). There are different anti-virulence targets, but the most studied are the quorum sensing (QS) systems (Jiang et al., 2019) and the type 3 secretion systems (T3SS) (Hotinger \& May, 2019).

QS is a phenomenon of gene regulation at the population level dependent on bacterial density that allows bacteria to exhibit collective or multicellular behaviors (Díaz-Nuñez, García-Contreras \& Castillo-Juárez, 2021). It is one of the best-studied anti-virulence targets because it regulates the expression of various virulence factors, including the formation of biofilms, which is a multicellular behavior that gives them high resistance to antimicrobials (Fleitas Martínez et al., 2018; Jiang et al., 2019).

122

In this regard, it is reported that some AMPs also exhibit anti-virulence properties at sub-inhibitory concentrations. In which the inhibition of biofilms (Di Somma et al., 2020), QS systems (Overhage et al., 2008), and secretion systems (McShan \& De Guzman, 2015) stand out. They also neutralize enzymes, such as exoproteases and toxins (Kudryashova, Seveau \& Kudryashov, 2017; Gusman bactericidal effect of antibiotics on resistant strains (Figure 1) (Geitani et al., 2019). 
129 This review focuses on describing and analyzing the anti-virulence properties of AMPs exhibited 130 in sub-inhibitory concentrations described so far, highlighting the evidence of their possible 131 application.

132

\section{Survey methodology}

134

135 To ensure an inclusive and unbiased analysis of literature and to accomplish the review's 136 objectives, a comprehensive analysis of published articles on the activity of antimicrobial peptides 137 using the following online databases: Medline (PubMed), Science Direct (http://sciencedirect.com) database, Web of Science, Scopus, and Google Scholar system. Additionally, the following keywords were used: antimicrobial peptides, anti-virulence properties, quorum sensing, biofilms, targets together with Boolean operators such as "AND” and "OR”.

\section{Anti-biofilm and anti-quorum sensing activity of AMPs}

Biofilms are the preferred lifestyle of bacteria and are structured microbial aggregates, surrounded by a self-produced extracellular matrix, and attached to biotic or abiotic surfaces. Biofilms are involved in most chronic bacterial infections (Bjarnsholt, 2013). Moreover, they are crucial determinants of bacterial virulence. The biofilm matrix is formed by diverse components present in the extracellular polymeric substances: mainly proteins, polysaccharides, extracellular nucleic acids, and ions (Donlan, 2002). Biofilm formation is an ordered process, beginning with the initial contact and attachment to surfaces, mainly mediated by structures such as flagellum and fimbria, followed by micro-colony formation, maturation, and formation of the complex biofilm

Biofilms are pivotal for bacterial survival as they protect against adverse environmental conditions. They increase drug resistance by various mechanisms such as the decrease in the permeability of antibiotics, the promotion of dormancy and induction of bacterial persistence, the expression of the efflux pumps of antibiotics, and the synthesis of periplasmic glucans (aminoglycosides) that inactivate antibiotics (Hall \& Mah, 2017). Biofilms also allow bacteria to evade the human defense 
160 mechanisms (Mirzaei et al., 2020) since several biofilm matrix proteins protect biofilms against 161 human innate immune cells, opsonization, and phagocytosis (Lewis, 2008). Moreover, it has been 162 demonstrated that some bacterial species, previously known as extracellular pathogens, can reside 163 inside various host cells by adapting to intracellular life through the formation of microbial 164 aggregates similar to bacterial biofilms, leading to their long-term survival inside the cells (Mirzaei 165 et al., 2020).

166

167 Unlike antibiotics, AMPs are suitable for slowing growth and killing cells in the biofilm. Several 168 examples of effective AMPs with this activity have been described that correlate with the ability 169 of AMPs to resolve bacterial infections in vivo. For a recent full review of these activities and the translation potential of such peptides, see the work of Gislaine and coworkers (Silveira et al., 171 2021).

172

173 Since the aim of this work is to discuss the anti-virulence potential of AMPs, and one of the 174 premises of anti-virulence therapies is not to affect directly bacterial growth and survival, most of the examples of AMPs with anti-biofilm activity discussed here will be peptides that inhibit biofilm formation at growth sub-inhibitory concentrations (Table 1).

AMP activity against biofilms is mediated by the degradation or destabilization of the extracellular matrix (Yasir, Willcox \& Dutta, 2018). The PI peptide (derived from polyphemusin I) induces the degradation of the exopolysaccharides produced by Streptococcus mutans, causing the biofilm formation to be attenuated (Zhang et al., 2019). Also, an AMP complex produced by the insect Calliphora vicina promotes the degradation of the matrix of the biofilm produced by E. coli, Staphylococcus aureus, and Acinetobacter baumannii (Gordya et al., 2017). Hepcidin 20 from the human liver decreases the extracellular matrix and disrupts the architecture of $S$. epidermidis biofilms (Brancatisano et al., 2014). S4 (1-16) M4Ka (dermaseptin S4 derivative), which inhibits immature biofilms of Pseudomonas fluorescens (Quilès et al., 2016). Piscidin-3 is derived from fish, which degrades the extracellular DNA of P. aeruginosa biofilms (Libardo et al., 2017).

Biofilm inhibition by AMPs is also mediated by the downregulation of genes responsible for 
$191 \beta$-defensin 3 from humans decreases the expression of the icaA, icaD, and icaR genes that codify 192 enzymes responsible for the biosynthesis of the adhesin PIA, essential for biofilm formation 193 (Rohde et al., 2010; Zhu et al., 2013). In addition, AMPs also inhibit genes that control the 194 transport and binding proteins, such as ABC transporters that are involved in biofilm formation 195 since they promote cell-to-surface and cell-to-cell interactions (Zhu et al., 2013; Wang et al., 196 2017).

197

198 Beyond inhibiting biofilm maturation, AMPs can also inhibit initial attachment and increase cell 199 dispersal. One of the first discovered AMPs with the ability to eradicate biofilms was LL-37 200 (Overhage et al., 2008), derived from human cathelicidin, an amphipathic peptide widely 201 distributed in body fluids (Burton \& Steel, 2009). At low concentrations, LL-37 inhibits the 202 adhesion of $P$. aeruginosa cells to surfaces, and at higher concentrations, it reduces the thickness 203 of the biofilms (Hancock \& Sahl, 2006). Moreover, LL-37 also eradicates P. aeruginosa biofilms 204 in vivo (Chennupati et al., 2009). The anti-biofilm effects of LL-37 in P. aeruginosa at 205 concentrations that do not affect viability and growth are related to the upregulation of the 206 expression of type IV pili genes that lead to the promotion of twitching motility which is linked to 207 biofilm dispersal and to the decrease in the expression of flagellar genes which leads to lower 208 attachment to surfaces (Overhage et al., 2008). In addition, LL-37 treatment induces a strong 209 down-regulation of the core genes of the Las and Rhl QS systems and the repression of genes that 210 encode QS-dependent virulence factors such as LasB elastase and those responsible for the 211 biosynthesis of rhamnolipids (Overhage et al., 2008). In addition, it inhibits the biofilm formation 212 of other pathogens such as Francisella novicida and S. epidermidis (Amer, Bishop \& van Hoek, 213 2010; Hell et al., 2010).

214 Other AMPs can prevent biofilm formation by inhibiting quorum sensing (Overhage et al., 2008).

215 For example, Trp-containing peptides inhibit QS-regulated virulence and biofilm growth of 216 multidrug-resistant P. aeruginosa. Significantly, peptides containing tryptophan at low 217 concentrations reduced the production of virulence factors that regulate the gene expression of the 218 Las and Rh1 systems. Biofilm formation was inhibited in a concentration-dependent manner, 219 which was associated with inhibiting extracellular polysaccharide production by negatively 220 regulating the transcription of $p e l A, \operatorname{alg} D$, and $p s l A$. These changes were correlated with alterations 221 in the extracellular production of virulence and motility. 
222 Also, two novel synthetic peptides (LIVRHK and LIVRRK) can inhibit biofilm formation of $P$. 223 aeruginosa PA01, and QS-dependent phenotypes such as pyocyanin exoprotease, and rhamnolipid 224 production were identified. In addition, a down-regulation of the expression of the core QS genes 225 lasRI and rhlRI were observed, corroborating the inhibition of QS (Taha et al., 2019).

226 The discovery of the anti-biofilm and anti-QS properties of LL-37 led to the search for other natural 227 and synthetic peptides with similar properties. De la Fuente and his colleagues in 2012 selected 50 228 small synthetic peptides and identified 16 with anti-biofilm activity against $P$. aeruginosa, with 229 HH15 being one of the best. According to their sequence, 15 small peptides were designed, 230 including peptide 1037 of only nine amino acids, reducing the biofilm formation of Burkholderia 231 cenocepacia and Listeria monocytogenes (De La Fuente-Núñez et al., 2012).

232

233 The peptide 1037, like LL-37, stimulates twitching motility and decreases the expression of 234 flagellar genes, leading to potent inhibition of swimming and swarming motilities (de la Fuente 235 Nuñez et al., 2012). Comparison between the effect in gene expression of peptides (LL-37 vs. 236 1037) allowed the identification of ten common downregulated genes and four upregulated ones. 237 The role of those genes in biofilm formation was confirmed using transposon mutants of each one, 238 being nine of the ten mutants in the downregulated genes lower biofilm producers than the parental 239 strain. Although the involved genes mainly were hypothetical proteins, the flagellar gene $\operatorname{fg} B$, $240 \mathrm{rhlB}$, involved in rhamnolipid biosynthesis and nirS encoding a nitrite reductase were identified. 241 In addition, two of the four mutants in the upregulated genes (a hypothetical protein and actP, 242 encoding an acetate permease have) higher biofilm producer than the parental strain (de la Fuente 243 Nuñez et al., 2012).

244 In another study, it was shown that LL-37 exhibits anti-biofilm activity against S. epidermidis, 245 where at low concentrations they prevent cell attachment, while at high concentrations, they 246 prevent the maturation and establishment of biofilms (Andersen et al., 2015). Also, LL-37 has a 247 potent $S$. aureus biofilm eradication activity (Kang, Dietz \& Li, 2019).

248 Other synthetic peptides such as D-Bac8 $\mathrm{c}^{2}$, 5Leu, D-HB43, and D-ranalexin have effectively killed 249 S. aureus biofilms. For example, the synthetic peptide D-Bac8c ${ }^{2}$, 5Leu, when applied as a catheter 250 lock solution, has inhibitory activity on early and mature $S$. aureus biofilms in a rat venous catheter 251 infection model (Zapotoczna et al., 2017). 
252 Although some classic antibiotics at sub-MIC concentrations have shown anti-virulence and QS

253 system regulation behaviors (Skindersoe et al., 2008; Zhang \& Li, 2016), there is still little research

254 on peptide antibiotics. However, bovicin HC5 (broad-spectrum lantibiotic) and nisin (polycyclic

255 peptide antibiotic) have been reported to have anti-biofilm activity through QS interference from

256 S. aureus (Pimentel-Filho et al., 2014). Similarly, subtilosin (cyclic lantibiotic) reduces violacein

257 production in Chromobacterium violaceum (indicative of QS inhibition), as well as biofilm

258 formation and autoinducer-2 (AI-2) production in Gardnerella vaginalis (Algburi et al. al., 2017)

259 (Table 1).

260

261 Other anti-virulence targets of AMPs

262

263 Although biofilms and other QS-controlled phenotypes (exoproteases, phenazines, rhamnolipids, 264 swarm motility) are essential for bacterial virulence, some important virulence factors are not 265 positively regulated by QS. Eight secretion systems have been found in Gram-negative and Gram266 positive bacteria. However, these systems are sometimes unregulated by QS or may even be 267 downregulated, as in some vibrio species. Therefore, in cases where QS negatively regulates them, 268 QS inhibition can promote virulence through secretion systems (Pena et al., 2019). Therefore, 269 specific inhibitors of these systems in combination with QS inhibitors may be necessary to develop 270 more robust antibacterial therapies (García-Contreras, 2016).

271

272 Accordingly, Zhang and coworkers elucidated the structural and functional details of the 273 pseudopilus tip complex of the type II secretion system of P. aeruginosa, which is an essential 274 component of the system that functions as a piston, allowing the export of multiple effectors 275 (Zhang et al., 2018). Based on the structural details of the complex, two mimicking peptides 276 [P1(EWESDNRLNEEQ) and P2 (TKLTRTWRQ)] that were able to compete with the binding of 277 the XcpV and XcpW pseudolipins were designed, retaining the specific amino acids that allow the 278 interaction between those pseudopilins and introducing other hydrophilic amino acids to enhance 279 solubility. The utilization of those peptides precluded the formation of the core complex essential 280 for the pseudopilus tip formation and strongly attenuated secretion through the type II secretion 281 system (Zhang et al., 2018). 
282 Interestingly, natural mammalian peptides, such as iron-binding lactoferrin, are potent inhibitors 283 of T3SS in enteric bacteria (Salmonella, Shigella, and E. coli) by inducing translocon protein 284 degradation. This activity is mediated by its binding to the lipopolysaccharide on the bacterial 285 surface, destabilizing the protein-protein interactions essential for the system. Furthermore, 286 lactoferrins have serine protease activity that can affect T3SS cleavage proteins (McShan and De 287 Guzman, 2015).

288 Beyond the anti-T3SS of natural peptides, the strategy of using polypeptides that mimic some 289 components of the systems and that compete with the binding of the natural bacterial components 290 was effective to inhibit the system in Chlamydia, Salmonella, and Shigella, blocking their entrance 291 to eukaryotic cells in cultures (McShan \& De Guzman, 2015). Similarly, in enteropathogenic $E$. 292 coli (EPEC), coiled-coil peptide mimetics, analogs of the EspA, EscF, and CesA proteins (CoilA, 293 294

Another critical virulence determinant is the type VI secretion system, which delivers multiple 296 effectors to prokaryotic and eukaryotic cells. Those effectors target cell walls, cell membranes, DNA, and to avoid self-poisoning, bacteria that produce them also produce neutralizing proteins 298 that bid the effectors. Recently, in P. aeruginosa, the effector TplE, a lipolytic toxin effective against other bacteria and able to disrupt the endoplasmic reticulum in eukaryotic cells, had been 300 characterized; this protein is neutralized by TplEi (Jiang et al., 2016).

301

302

Based on this interaction, Gao and coworkers generated a small peptide capable of competing with 303 the TplEi-TplE interaction, for this TplE was hydrolyzed, generating a 26 amino acid fragment 304 that strongly binds with TplEi, releasing the TplE toxin, and thus inducing the autointoxication of 305 P. aeruginosa (Gao et al., 2017). This approach is attractive and represents a new concept for 306 generating new inhibitors of secretory systems and other potential targets. A similar approach was 307 recently used for the identification of small peptides that inhibit antitoxins that belong to the toxinantitoxin systems (Lee et al., 2015; Sundar, Rajan \& Piramanayagam, 2019), which are related to 309 latency, persistence (Page \& Peti, 2016) and bacterial virulence (Fernández-García et al., 2016). These systems are abundant in intracellular bacterial pathogens such as Mycobacterium tuberculosis (Sala, Bordes \& Genevaux, 2014). 
313 Additional anti-virulence activities of some AMPs, such as defensins are the capacity to bind and 314 inhibit the activity of several bacterial toxins and related virulence factors (Table 1). Defensins are 315 components of the innate immunity of mammals and are also found in invertebrates, plants, and 316 fungi. Although these peptides had low sequence similarity, they share common structural features 317 and display broad antibacterial and antiviral activity at high concentrations; in addition, they 318 modulate inflammation and promote angiogenesis and wound healing. Moreover, they can 319 neutralize several bacterial toxins, among them cytolysin, listeryolysin that promote pore 320 formation, ribosyltransferase toxins, glycosylation promoting toxins, the MARTX toxins from 321 Vibrio and Aeromonas, the Panton-Valentine leucocidin, staphylokinase from S. aureus, SIC 322 which is the Streptococcal inhibitor of complement (Kudryashova, Seveau \& Kudryashov, 2017). 323 Upon binding to the toxins, defensins promote their unfolding, disrupting their secondary and 324 tertiary structure, making them more susceptible to proteolysis and promoting their precipitation. 325 Although the physicochemical properties that allow defensins to bind and neutralize a broad range 326 of structurally diverse toxins are not completely understood, recent studies demonstrate that 327 defensins act by recognizing regions of proteins showing structural plasticity and thermodynamic 328 instability, features that are shared by a wide range of bacterial toxins (Kudryashova, Seveau \& Kudryashov, 2017). In general, of the alpha-class such as HNP and HD5, they inhibit the lethal 330 factor of Bacillus anthracis, the diphtheria toxin, the exotoxin A of P. aeruginosa, the cytotoxin 331 B of Clostridioides difficile, among others (Kim et al. 2005, 2006; Giesemann et al., 2008). While those in the beta-class, such as hBD, inhibit the gonococcal toxin NarE from Neisseria gonorrhoeae and the lethal factor from B. anthracis (Rodas et al., 2016; Wei et al., 2009). In the case of those of the theta-class, the retrocyclins inhibit the lethal factor of B. anthracis and the vaginolysin of G. vaginalis (Wang et al., 2006; Hooven et al., 2012).

Beyond defensins, there are other notable examples of toxin-neutralizing peptides, such as the 338 artificial peptide Pep19-2.5 and related ones, capable of inactivating lipopolysaccharides (LPS or endotoxin) and lipoproteins in vitro and in vivo. They also decrease inflammation mediated by the activation of signaling cascades (Heinbockel et al., 2018), and their efficacy has been reported in several mouse infection models, including endotoxemia and bacteremia (Heinbockel et al., 2013).

342 Several other peptides with the ability to neutralize a wide variety of bacterial toxins have been 343 described, for which we recommend consulting the following reviews (Jerala \& Porro, 2005; 
344 Kudryashova, Seveau \& Kudryashov, 2017; Schnell et al., 2019). The effect was not always 345 determined at sub-MIC concentrations; however, the inhibition of toxins is a strategy contemplated 346 within the anti-virulence targets.

347 Bacitracin is an antibiotic that inhibits cell wall synthesis, but recently it has also been reported to 348 neutralize type $\mathrm{A} / \mathrm{B}$ protein exotoxins by inhibiting pore formation, preventing translocation of the 349 A subunit to the host cell cytosol. These toxins are made up of an enzymatic component (A subunit) 350 and a binding/transport component (B subunit), such as the lethal factor of Bacillus anthracis, the 351 toxin $\mathrm{C} 2$ of Clostridium botulinum, the CDT transferase of $C$. difficile, and epsilon toxin of 352 Clostridium perfringens (Schnell et al., 2019). In addition to neutralizing bacterial toxins, some 353 AMPs can inhibit exoproteases implicated in the generation of host damage during periodontal 354 disease. For example, the salivary peptide histatin 5 inhibits the host metalloproteases and 355 exoproteases from bacterial pathogens such as the gingipains produced by Porphyromonas 356 gingivalis attenuating damage and inflammation (Gusman et al., 2001). Moreover, histatin 5 also

357 358

359

360

361

362

363

364

365 366

367 368 369

370 371 372

\section{Conclusions}

374 2020). inhibits cysteine proteinases such as clostripain, which is produced by Clostridium histolyticum during gangrene, while other AMPs inhibit exoproteases such as subtilisin A, proteinase $\mathrm{K}$, elastase, and chymotrypsin (Le, Fang \& Sekaran, 2017).

Finally, a characteristic of some anti-virulence molecules is their adjuvant properties, which enable them to restore the activity of antibiotics on resistant strains (Díaz-Nuñez, García-Contreras \& Castillo-Juárez, 2021). This strategy is very promising, and although it does not prevent the generation of resistance, it allows the reactivation of antimicrobials that are in danger of falling into disuse (González-Bello, 2017). In the case of AMPs at sub-MIC concentrations, some reports of adjuvant properties have been made in the literature, such as unarmycin A and C (Tanabe et al., 2007). These cyclopeptides isolated from marine bacteria are azole antifungal ejection pump inhibitors and restore fluconazole sensitivity of resistant strains and clinical isolates of Candida albicans (Tanabe et al., 2007). Also, plantaricin PLNC8 $\alpha \beta$ showed an adjuvant effect by potentiating the activity of conventional antibiotics (vancomycin, rifampicin, and gentamicin) against $S$. epidermidis, although the mechanism of action involved is unknown (Bengtsson et al.,

Peer) reviewing PDF | (2021:10:67017:1:0:NEW 29 Nov 2021) 
375 There is currently enough evidence to support the participation of the QS, T3S, two-component 376 regulatory systems, and other virulence determinants in the generation of bacterial pathogenicity 377 and damage (Marshall \& Brett Finlay, 2014; Totsika, 2016; Tiwari et al., 2017; Tsai et al., 2020).

378 It is reported that the interruption of genes that code for these systems reduces virulence and 379 bacterial pathogenicity in vivo models of animals and plants (Castillo-Juárez et al., 2015; Jiang et 380 al., 2019). Also, similar results are obtained with the administration of small molecules that inhibit 381 these systems (Marshall \& Brett Finlay, 2014; Jiang et al., 2016; Hotinger \& May, 2019). 382 Similarly, there are reports of the anti-virulence properties of synthetic peptides analogous to the 383 autoinducers of Gram-positive bacteria, such as the so-called RIP and its derivatives (RBP15), 384 which reduce pathogenicity at the preclinical level (Yang et al., 2003; Singh, Desouky \& Nakayama, 2016). However, to achieve the implementation of anti-virulence therapies in the clinical practice, there are some challenges to overcome, such as determining their toxicity, their possible side effects, including their effects on the microbiota, the generation of resistance, and verifying their efficacy at the clinical level (Díaz-Nuñez, García-Contreras \& Castillo-Juárez, 389 2021).

390

391

392

393

394 395

396 397

The anti-virulence effects of substances at low concentrations has generated significant interest due to the possibility of controlling microbial infections and probably avoiding the appearance of resistance (Totsika, 2016; Díaz-Nuñez, García-Contreras \& Castillo-Juárez, 2021). Various substances, including natural products, antibiotics, and drugs of mass consumption such as ibuprofen and aspirin have been identified to reduce virulence at sub-MIC concentrations (Bernardo et al., 2004; Skindersoe et al., 2008; El-Mowafy et al., 2014; Soo et al., 2017; Dai et al., 2019). The information related to the effect of low-dose AMPs is scarce and highly debatable. Recently, evidence that indicates adverse effects of the use of AMP at sub-inhibitory doses was compiled. The possible adverse effects include the induction of resistance (strong stress generators) and directly or indirectly stimulating virulence through different signaling pathways (Vasilchenko \& Rogozhin, 2019). It should be noted that the main characteristic of the ideal antivirulence molecule is that it does not interfere directly with bacterial viability, lowering the selection pressure for the generation of resistance (Díaz-Nuñez, García-Contreras \& CastilloJuárez, 2021). Most peptides stress bacterial cells at growth inhibitory concentrations; however, there is evidence to suggest that in their native environment, peptides are in relatively low 
406 concentrations that do not kill microorganisms, and hence the high growth inhibitory 407 concentrations are hardly reached (Dorschner et al., 2001; Monnet, Juillard \& Gardan, 2016; 408 Vasilchenko \& Rogozhin, 2019). Therefore, the ubiquitous microbicidal activity of AMPs may 409 not be their primary natural or ecological function.

410

411 Also, it has been pointed out that AMPs exhibit anti-virulence properties, but the effect is 412 unpredictable and possibly uncontrollable since AMPs also may stimulate virulence at specific 413 concentrations (Vasilchenko \& Rogozhin, 2019). In this regard, hormesis is a widely studied 414 phenomenon that occurs at low doses, in which the same compound can exhibit antagonistic effects 415 depending on the dose (Mattson, 2008). This phenomenon has been described in some small and 416 synthetic molecules, but it is not a generality for all the anti-virulence molecules described. In the 417 case of AMPs, a possible case of hormesis of the LL-37 peptide is pointed out, which at sub-MIC 418 concentrations reduces the gene expression of QS and the production of virulence factors, but at 419 the same time stimulates others (Overhage et al., 2008; Strempe et al., 2013). In hormesis, 420 concentration is essential to obtain the desired effect; however, identifying peptides that can 421 stimulate QS systems could be helpful if applied to bacteria that regulate the expression of 422 beneficial phenotypes. As in the case of beneficial microorganisms in agriculture, for the treatment 423 of wastewater or the intestinal microbiota (Schikora, Schenk \& Hartmann, 2016; Zhang \& Li, 424 2016; Bivar Xavier, 2018). In this sense, nanotechnological techniques will be essential to help to 425 maintain their bioavailability efficiently (Boparai \& Sharma, 2019).

427 With the information available to date, some behaviors, or effects of peptides at sub-MIC 428 concentrations can be classified as autoinducer peptides, inducer peptides, signal peptides, and 429 anti-virulence peptides (Figure 2). Autoinducer peptides are produced by Gram-positive bacteria 430 [AIP (autoinducing peptide), CSP (competence stimulating peptide), ComX, and CSF 431 (competence and sporulation factor)] and participate in bacterial communication through QS 432 systems (Monnet, Juillard \& Gardan, 2016). In comparison, the inducer peptides are those that are 433 produced by other microorganisms (antibiotics, bacteriocins) or the host (defensins) and that 434 modify the gene expression of the QS systems or virulence (Baishya et al., 2021). The signaling 435 peptides are produced by host cells for specific functions (such as promoting the establishment of 436 beneficial microorganisms of the intestinal microbiota), but bacteria also capture them as 
437 environmental signals for regulating virulence systems. Finally, anti-virulence peptides are 438 produced by the hosts (or by competing microorganisms) as a strategy to reduce pathogenicity and 439 avoid the establishment and damage of bacteria (Figure 2). It should be noted that one and two440 component environmental signaling systems can participate in all these effects (Tiwari et al., 441 2017).

442

443 Some authors mention the term "pheromone" to refer to the induction of gene expression "at a 444 distance" (distances are challenging to define in the microscopic world) by specific peptides 445 (Monnet, Juillard \& Gardan, 2016; Yajima, 2016; Vasilchenko \& Rogozhin, 2019). However, we 446 consider it a confusing term and suggest that it should be avoided in this study topic as it is based 447 on an analogy of the functioning of pheromones in macroscopic organisms with sexual 448 reproduction. Likewise, in the classification by activity of anti-virulence peptides, their possible 449 effects on host cells should be considered (Tornesello et al., 2018) as well as their immunogenic 450 activity, which some authors point out is the main responsible for eliminating bacteria in vivo 451 (Hancock \& Sahl, 2013; Mansour, Pena \& Hancock, 2014).

452

453 On the other hand, although the U.S. Food and Drug Administration (FDA) has approved several 454 AMPs used at growth inhibitory concentrations, most are restricted to the topical application due 455 to limitations found with other routes of administration, such as a short half-life, low stability, and 456 low bioavailability (Lei et al., 2019). Likewise, its use at inhibitory concentrations for prolonged 457 periods is reported to generate toxic effects, like hemolysis, and to induce resistance 458 (Rathinakumar, Walkenhorst \& Wimley, 2009; Starr et al., 2018; Lei et al., 2019), coupled with 459 the high cost of producing them commercially (Moretta et al., 2021). Investigating the activities 460 of AMPs at low or growth sub-inhibitory concentrations could help resolve some of these 461 difficulties and favor their clinical application. Therefore, we can conclude that the action of AMPs 462 and the response they elicit at sub-MIC concentrations is a fertile and promising area of knowledge 463 that requires further research to develop safe and effective anti-virulence therapies.

465 Finally, regardless of the anti-biofilm and anti-virulence properties of the peptides discussed here, 466 some aspects should be further tested, including their utilization to attenuate infections produced 
467 by clinical strains in vivo, and more significant efforts for their implementation in clinical trials 468 should be encouraged (Silveira et al., 2021).

469

470 Another aspect that needs to be studied further is the mechanistic details of the action of peptides 471 that inhibit biofilm formation (without affecting bacterial growth), virulence factors controlled by 472 QS, and secretion systems. It is essential to study the possibility of selecting resistance in vivo, its 473 effects, and the mechanisms involved. Although it is proposed that the peptides are more robust 474 and less likely to induce resistance compared to the usual antibiotics, some possible mechanisms 475 are proposed, such as modifications of the membrane and the composition of the cell wall, 476 expulsion by efflux pumps, AMP sequestration, and protease inactivation (Assoni et al., 2020). In 477 this regard, it is expected that similar mechanisms will eventually evolve to attenuate the effects 478 of AMP on biofilm and inhibit virulence, even if these peptides do not affect viability and growth 479 in vitro in principle.

480 It was especially considering that although scarce, resistance mechanisms against anti-virulence 481 therapies, mediated by QS inhibition (García-Contreras, 2016) and biofilm inhibition, had been 482 described (Travier et al., 2013).

483

484

\section{Acknowledgements}

485

486

AM F-P is funded by from PAPITT, DGAPA, UNAM, Mexico City, grant \#IN218419, R G-C is 487 funded by CONACYT grant CB 2017-2018 number A1-S-8530 and by PAPITT UNAM grant 488 number IN214218. I C-J is funded by Cátedras-CONACyT program. BE B-L is supported by CONACYT grant \# 424031 for her doctoral studies.

490

491

492

493

494

495

496

497

498

499

500

\section{References}

Alghalayini A, Garcia A, Berry T, Cranfield CG. 2019. The use of tethered bilayer lipid membranes to identify the mechanisms of antimicrobial peptide interactions with lipid bilayers. Antibiotics 8. DOI: 10.3390/antibiotics8010012.

Baishya J, Bisht K, Rimbey JN, Yihunie KD, Islam S, Mahmud H Al, Waller JE, Wakeman CA. 2021. The impact of intraspecies and interspecies bacterial interactions on disease outcome. Pathogens 10. DOI: 10.3390/pathogens10020096. 
501

502

503

504

505

506

507

508

509

510

511

512

513

514

515

516

517

518

519

520

521

522

523

524

525

526

527

528

529

530

531

532

533

534

535

536

537

538

539

540

541

542

543

544

545

546

Barreto-Santamaría A, Curtidor H, Arévalo-Pinzón G, Herrera C, Suárez D, Pérez WH, Patarroyo ME. 2016. A new synthetic peptide having two target of antibacterial action in E. coli ML35. Frontiers in Microbiology 7. DOI: 10.3389/fmicb.2016.02006.

Beisswenger C, Bals R. 2005. Functions of Antimicrobial Peptides in Host Defense and Immunity. Current Protein \& Peptide Science 6. DOI: 10.2174/1389203054065428. Bengtsson T, Selegård R, Musa A, Hultenby K, Utterström J, Sivlér P, Skog M, Nayeri F, Hellmark B, Söderquist B, Aili D, Khalaf H. 2020. Plantaricin NC8 $\alpha \beta$ exerts potent antimicrobial activity against Staphylococcus spp. and enhances the effects of antibiotics. Scientific Reports 10. DOI: 10.1038/s41598-020-60570-w.

Bernardo K, Pakulat N, Fleer S, Schnaith A, Utermöhlen O, Krut O, Müller S, Krönke M. 2004. Subinhibitory Concentrations of Linezolid Reduce Staphylococcus aureus Virulence Factor Expression. Antimicrobial Agents and Chemotherapy 48. DOI: 10.1128/AAC.48.2.546555.2004.

Besse A, Peduzzi J, Rebuffat S, Carré-Mlouka A. 2015. Antimicrobial peptides and proteins in the face of extremes: Lessons from archaeocins. Biochimie 118. DOI: 10.1016/j.biochi.2015.06.004.

Bivar Xavier K. 2018. Bacterial interspecies quorum sensing in the mammalian gut microbiota. Comptes Rendus - Biologies 341. DOI: 10.1016/j.crvi.2018.03.006.

Bjarnsholt T. 2013. The role of bacterial biofilms in chronic infections. APMIS 121. DOI: 10.1111/apm.12099.

Boman HG. 2000. Innate immunity and the normal microflora. Immunological Reviews 173. DOI: 10.1034/j.1600-065X.2000.917301.x.

Boparai JK, Sharma PK. 2019. Mini Review on Antimicrobial Peptides, Sources, Mechanism and Recent Applications. Protein \& Peptide Letters 27. DOI: 10.2174/0929866526666190822165812.

Brancatisano FL, Maisetta G, Di Luca M, Esin S, Bottai D, Bizzarri R, Campa M, Batoni G. 2014. Inhibitory effect of the human liver-derived antimicrobial peptide hepcidin 20 on biofilms of polysaccharide intercellular adhesin (PIA)-positive and PIA-negative strains of Staphylococcus epidermidis. Biofouling 30. DOI: 10.1080/08927014.2014.888062.

Brogden KA. 2005. Antimicrobial peptides: Pore formers or metabolic inhibitors in bacteria? Nature Reviews Microbiology 3. DOI: 10.1038/nrmicro1098.

Brötz H, Bierbaum G, Leopold K, Reynolds PE, Sahl HG. 1998. The lantibiotic mersacidin inhibits peptidoglycan synthesis by targeting lipid II. Antimicrobial Agents and Chemotherapy 42. DOI: 10.1128/aac.42.1.154.

Bulet P, Stöcklin R, Menin L. 2004. Anti-microbial peptides: From invertebrates to vertebrates. Immunological Reviews 198. DOI: 10.1111/j.0105-2896.2004.0124.x.

Burton MF, Steel PG. 2009. The chemistry and biology of LL-37. Natural Product Reports 26. DOI: $10.1039 / \mathrm{b} 912533 \mathrm{~g}$.

Cassone M, Frith N, Vogiatzi P, Wade JD, Otvos L. 2009. Induced resistance to the designer proline-rich antimicrobial peptide A3-APO does not involve changes in the intracellular target DnaK. International Journal of Peptide Research and Therapeutics 15. DOI: 10.1007/s10989-009-9176-1.

Castillo-Juarez I, López-Jácome LE, Soberón-Chávez G, Tomás M, Lee J, Castañeda-Tamez P, Hernández-Bárragan IA, Cruz-Muñiz MY, Maeda T, Wood TK, García-Contreras R. 2017. Exploiting quorum sensing inhibition for the control of pseudomonas aeruginosa and acinetobacter baumannii biofilms. Current Topics in Medicinal Chemistry 17. DOI:

Peer) reviewing PDF | (2021:10:67017:1:0:NEW 29 Nov 2021) 
547

548

549

550

551

552

553

554

555

556

557

558

559

560

561

562

563

564

565

566

567

568

569

570

571

572

573

574

575

576

577

578

579

580

581

582

583

584

585

586

587

588

589

590

591

592

$10.2174 / 1568026617666170105144104$.

Castillo-Juárez I, Maeda T, Mandujano-Tinoco EA, Tomás M, Pérez-Eretza B, García-Contreras SJ, Wood TK, García-Contreras R. 2015. Role of quorum sensing in bacterial infections. World Journal of Clinical Cases. DOI: 10.12998/wjcc.v3.i7.575.

Chennupati SK, Chiu AG, Tamashiro E, Banks CA, Cohen MB, Bleier BS, Konofow JM, Tam E, Cohen NA. 2009. Effects of an LL-37-derived antimicrobial peptide in an animal model of biofilm Pseudomonas sinusitis. American Journal of Rhinology and Allergy 23. DOI: 10.2500/ajra.2009.23.3261.

Dai L, Wu T qi, Xiong Y song, Ni H bing, Ding Y, Zhang W chen, Chu S peng, Ju S qing, Yu J. 2019. Ibuprofen-mediated potential inhibition of biofilm development and quorum sensing in Pseudomonas aeruginosa. Life Sciences 237. DOI: 10.1016/j.lfs.2019.116947.

Díaz-Nuñez JL, García-Contreras R, Castillo-Juárez I. 2021. The New Antibacterial Properties of the Plants: Quo vadis Studies of Anti-virulence Phytochemicals? Frontiers in Microbiology 12. DOI: 10.3389/fmicb.2021.667126.

Donlan RM. 2002. Biofilms: Microbial life on surfaces. Emerging Infectious Diseases 8. DOI: 10.3201/eid0809.020063.

Dorschner RA, Pestonjamasp VK, Tamakuwala S, Ohtake T, Rudisill J, Nizet V, Agerberth B, Gudmundsson GH, Gallo RL. 2001. Cutaneous injury induces the release of cathelicidin anti-microbial peptides active against group A streptococcus. Journal of Investigative Dermatology 117. DOI: 10.1046/j.1523-1747.2001.01340.x.

El-Mowafy SA, Abd El Galil KH, El-Messery SM, Shaaban MI. 2014. Aspirin is an efficient inhibitor of quorum sensing, virulence and toxins in Pseudomonas aeruginosa. Microbial Pathogenesis 74. DOI: 10.1016/j.micpath.2014.07.008.

Fleitas Martínez O, Rigueiras PO, Pires Á da S, Porto WF, Silva ON, de la Fuente-Nunez C, Franco OL. 2018. Interference With Quorum-Sensing Signal Biosynthesis as a Promising Therapeutic Strategy Against Multidrug-Resistant Pathogens. Frontiers in cellular and infection microbiology 8. DOI: 10.3389/fcimb.2018.00444.

González-Bello C. 2017. Antibiotic adjuvants - A strategy to unlock bacterial resistance to antibiotics. Bioorganic and Medicinal Chemistry Letters 27. DOI: 10.1016/j.bmcl.2017.08.027.

Graf M, Wilson DN. 2019. Intracellular antimicrobial peptides targeting the protein synthesis machinery. In: Advances in Experimental Medicine and Biology. DOI: 10.1007/978-981-133588-4_6.

Hancock REW, Sahl HG. 2006. Antimicrobial and host-defense peptides as new anti-infective therapeutic strategies. Nature Biotechnology 24. DOI: 10.1038/nbt1267.

Hancock REW, Sahl HG. 2013. New strategies and compounds for anti-infective treatment. Current Opinion in Microbiology 16. DOI: 10.1016/j.mib.2013.08.004.

Haney EF, Straus SK, Hancock REW. 2019. Reassessing the host defense peptide landscape. Frontiers in Chemistry 7. DOI: 10.3389/fchem.2019.00043.

Harris F, Dennison S, Phoenix D. 2009. Anionic Antimicrobial Peptides from Eukaryotic Organisms. Current Protein \& Peptide Science 10. DOI: 10.2174/138920309789630589.

Hooven TA, Randis TM, Hymes SR, Rampersaud R, Ratner AJ. 2012. Retrocyclin inhibits Gardnerella vaginalis biofilm formation and toxin activity. Journal of Antimicrobial Chemotherapy 67. DOI: 10.1093/jac/dks305.

Hotinger JA, May AE. 2019. Animal models of type III secretion system-mediated pathogenesis. Pathogens 8. DOI: 10.3390/pathogens8040257.

PeerJ reviewing PDF | (2021:10:67017:1:0:NEW 29 Nov 2021) 
593

594

595

596

597

598

599

600

601

602

603

604

605

606

607

608

609

610

611

612

613

614

615

616

617

618

619

620

621

622

623

624

625

626

627

628

629

630

631

632

633

634

635

636

637

638

Huan Y, Kong Q, Mou H, Yi H. 2020. Antimicrobial Peptides: Classification, Design, Application and Research Progress in Multiple Fields. Frontiers in Microbiology 11. DOI: 10.3389/fmicb.2020.582779.

Jerala R, Porro M. 2005. Endotoxin Neutralizing Peptides. Current Topics in Medicinal Chemistry 4. DOI: 10.2174/1568026043388079.

Jiang Q, Chen J, Yang C, Yin Y, Yao K, Song D. 2019. Quorum Sensing: A Prospective Therapeutic Target for Bacterial Diseases. BioMed Research International 2019. DOI: $10.1155 / 2019 / 2015978$.

Jiang F, Wang X, Wang B, Chen L, Zhao Z, Waterfield NR, Yang G, Jin Q. 2016. The Pseudomonas aeruginosa Type VI Secretion PGAP1-like Effector Induces Host Autophagy by Activating Endoplasmic Reticulum Stress. Cell Reports 16. DOI:

10.1016/j.celrep.2016.07.012.

Kudryashova E, Seveau SM, Kudryashov DS. 2017. Targeting and inactivation of bacterial toxins by human defensins. Biological Chemistry 398. DOI: 10.1515/hsz-2017-0106.

De La Fuente-Núñez C, Korolik V, Bains M, Nguyen U, Breidenstein EBM, Horsman S, Lewenza S, Burrows L, Hancock REW. 2012. Inhibition of bacterial biofilm formation and swarming motility by a small synthetic cationic peptide. Antimicrobial Agents and Chemotherapy 56. DOI: 10.1128/AAC.00064-12.

de la Fuente-Núñez C, Silva ON, Lu TK, Franco OL. 2017. Antimicrobial peptides: Role in human disease and potential as immunotherapies. Pharmacology and Therapeutics 178. DOI: 10.1016/j.pharmthera.2017.04.002.

Larzábal M, Baldoni HA, Suvire FD, Curto LM, Gomez GE, Da Silva WM, Giudicessi SL, Camperi SA, Delfino JM, Cataldi AA, Enriz D. 2019. An inhibitory mechanism of action of coiled-coil peptides against type three secretion system from enteropathogenic Escherichia coli. Journal of Peptide Science 25. DOI: 10.1002/psc.3149.

Le CF, Fang CM, Sekaran SD. 2017. Intracellular targeting mechanisms by antimicrobial peptides. Antimicrobial Agents and Chemotherapy 61. DOI: 10.1128/AAC.02340-16.

Lei J, Sun LC, Huang S, Zhu C, Li P, He J, Mackey V, Coy DH, He QY. 2019. The antimicrobial peptides and their potential clinical applications. American Journal of Translational Research 11.

Lewis K. 2008. Multidrug tolerance of biofilms and persister cells. Current Topics in Microbiology and Immunology 322. DOI: 10.1007/978-3-540-75418-3_6.

Magana M, Pushpanathan M, Santos AL, Leanse L, Fernandez M, Ioannidis A, Giulianotti MA, Apidianakis Y, Bradfute S, Ferguson AL, Cherkasov A, Seleem MN, Pinilla C, de la Fuente-Nunez C, Lazaridis T, Dai T, Houghten RA, Hancock REW, Tegos GP. 2020. The value of antimicrobial peptides in the age of resistance. The Lancet Infectious Diseases 20. DOI: $10.1016 /$ S1473-3099(20)30327-3.

Mankoci S, Ewing J, Dalai P, Sahai N, Barton HA, Joy A. 2019. Bacterial Membrane Selective Antimicrobial Peptide-Mimetic Polyurethanes: Structure-Property Correlations and Mechanisms of Action. Biomacromolecules 20. DOI: 10.1021/acs.biomac.9b00939.

Mansour SC, Pena OM, Hancock REW. 2014. Host defense peptides: Front-line immunomodulators. Trends in Immunology 35. DOI: 10.1016/j.it.2014.07.004.

Marshall NC, Brett Finlay B. 2014. Targeting the type III secretion system to treat bacterial infections. Expert Opinion on Therapeutic Targets 18. DOI:

10.1517/14728222.2014.855199.

Mattson MP. 2008. Hormesis defined. Ageing Research Reviews 7. DOI:

Peer] reviewing PDF | (2021:10:67017:1:0:NEW 29 Nov 2021) 
639

640

641

642

643

644

645

646

647

648

649

650

651

652

653

654

655

656

657

658

659

660

661

662

663

664

665

666

667

668

669

670

671

672

673

674

675

676

677

678

679

680

681

682

683

684

10.1016/j.arr.2007.08.007.

McShan AC, De Guzman RN. 2015. The Bacterial Type III Secretion System as a Target for Developing New Antibiotics. Chemical Biology and Drug Design 85. DOI:

10.1111/cbdd.12422.

Mirzaei R, Mohammadzadeh R, Alikhani MY, Shokri Moghadam M, Karampoor S, Kazemi S, Barfipoursalar A, Yousefimashouf R. 2020. The biofilm-associated bacterial infections unrelated to indwelling devices. IUBMB Life 72. DOI: 10.1002/iub.2266.

Monnet V, Juillard V, Gardan R. 2016. Peptide conversations in Gram-positive bacteria. Critical Reviews in Microbiology 42. DOI: 10.3109/1040841X.2014.948804.

Moretta A, Scieuzo C, Petrone AM, Salvia R, Manniello MD, Franco A, Lucchetti D, Vassallo A, Vogel H, Sgambato A, Falabella P. 2021. Antimicrobial Peptides: A New Hope in Biomedical and Pharmaceutical Fields. Frontiers in Cellular and Infection Microbiology 11. DOI: 10.3389/fcimb.2021.668632.

Muñoz-Cazares N, García-Contreras R, Pérez-López M, Castillo-Juárez I. 2017. Phenolic Compounds with Anti-virulence Properties. In: Phenolic Compounds - Biological Activity. DOI: $10.5772 / 66367$.

Overhage J, Campisano A, Bains M, Torfs ECW, Rehm BHA, Hancock REW. 2008. Human host defense peptide LL-37 prevents bacterial biofilm formation. Infection and Immunity 76. DOI: 10.1128/IAI.00318-08.

Pasupuleti M, Schmidtchen A, Malmsten M. 2012. Antimicrobial peptides: Key components of the innate immune system. Critical Reviews in Biotechnology 32. DOI: 10.3109/07388551.2011.594423.

Patrzykat A, Friedrich CL, Zhang L, Mendoza V, Hancock REW. 2002. Sublethal concentrations of pleurocidin-derived antimicrobial peptides inhibit macromolecular synthesis in Escherichia coli. Antimicrobial Agents and Chemotherapy 46. DOI: 10.1128/AAC.46.3.605-614.2002.

Rathinakumar R, Walkenhorst WF, Wimley WC. 2009. Broad-spectrum antimicrobial peptides by rational combinatorial design and high-throughput screening: The importance of interfacial activity. Journal of the American Chemical Society 131. DOI: $10.1021 / \mathrm{ja} 8093247$.

Rohde H, Frankenberger S, Zähringer U, Mack D. 2010. Structure, function and contribution of polysaccharide intercellular adhesin (PIA) to Staphylococcus epidermidis biofilm formation and pathogenesis of biomaterial-associated infections. European Journal of Cell Biology 89. DOI: $10.1016 /$ j.ejcb.2009.10.005.

Schikora A, Schenk ST, Hartmann A. 2016. Beneficial effects of bacteria-plant communication based on quorum sensing molecules of the $\mathrm{N}$-acyl homoserine lactone group. Plant Molecular Biology 90. DOI: 10.1007/s11103-016-0457-8.

Schnell L, Felix I, Müller B, Sadi M, Von Bank F, Papatheodorou P, Popoff MR, Aktories K, Waltenberger E, Benz R, Weichbrodt C, Fauler M, Frick M, Barth H. 2019. Revisiting an old antibiotic: Bacitracin neutralizes binary bacterial toxins and protects cells from intoxication. FASEB Journal 33. DOI: 10.1096/fj.201802453R.

Silveira GGOS, Torres MDT, Ribeiro CFA, Meneguetti BT, Carvalho CME, De La FuenteNunez C, Franco OL, Cardoso MH. 2021. Antibiofilm Peptides: Relevant Preclinical Animal Infection Models and Translational Potential. ACS Pharmacology and Translational Science 4. DOI: 10.1021/acsptsci.0c00191.

Singh RP, Desouky SE, Nakayama J. 2016. Quorum quenching strategy targeting gram-positive

Peer] reviewing PDF | (2021:10:67017:1:0:NEW 29 Nov 2021) 
685

686

687

688

689

690

691

692

693

694

695

696

697

698

699

700

701

702

703

704

705

706

707

708

709

710

711

712

713

714

715

716

717

718

719

720

721

722

723

724

725

726

727

728

729

730

pathogenic bacteria. In: Advances in Experimental Medicine and Biology. DOI: 10.1007/5584_2016_1.

Skindersoe ME, Alhede $\bar{M}$, Phipps R, Yang L, Jensen PO, Rasmussen TB, Bjarnsholt T, TolkerNielsen T, Høiby N, Givskov M. 2008. Effects of antibiotics on quorum sensing in Pseudomonas aeruginosa. Antimicrobial Agents and Chemotherapy 52. DOI: 10.1128/AAC.01230-07.

Soltani S, Hammami R, Cotter PD, Rebuffat S, Said L Ben, Gaudreau H, Bédard F, Biron E, Drider D, Fliss I. 2021. Bacteriocins as a new generation of antimicrobials: Toxicity aspects and regulations. FEMS Microbiology Reviews 45. DOI: 10.1093/femsre/fuaa039.

Di Somma A, Avitabile C, Cirillo A, Moretta A, Merlino A, Paduano L, Duilio A, Romanelli A. 2020. The antimicrobial peptide Temporin L impairs E. coli cell division by interacting with FtsZ and the divisome complex. Biochimica et Biophysica Acta - General Subjects 1864. DOI: $10.1016 /$ j.bbagen.2020.129606.

Soo VWC, Kwan BW, Quezada H, Castillo-Juárez I, Pérez-Eretza B, García-Contreras SJ, Martínez-Vázquez M, Wood TK, García-Contreras R. 2017. Repurposing of anticancer drugs for the treatment of bacterial infections. Current Topics in Medicinal Chemistry 17. DOI: $10.2174 / 1568026616666160930131737$.

Starr CG, Maderdrut JL, He J, Coy DH, Wimley WC. 2018. Pituitary adenylate cyclaseactivating polypeptide is a potent broad-spectrum antimicrobial peptide: Structure-activity relationships. Peptides 104. DOI: 10.1016/j.peptides.2018.04.006.

Strempe N, Neidig A, Nusser M, Geffers R, Vieillard J, Lesouhaitier O, Brenner-Weiss G, Overhage J. 2013. Human host defense peptide LL-37 Stimulates virulence factor production and adaptive resistance in Pseudomonas aeruginosa. PLOS ONE 8. DOI: 10.1371/journal.pone.0082240.

Subbalakshmi C, Sitaram N. 1998. Mechanism of antimicrobial action of indolicidin. FEMS Microbiology Letters 160. DOI: 10.1016/S0378-1097(98)00008-1.

Sutherland IW. 2001. The biofilm matrix - An immobilized but dynamic microbial environment. Trends in Microbiology 9. DOI: 10.1016/S0966-842X(01)02012-1.

Tanabe K, Lamping E, Adachi K, Takano Y, Kawabata K, Shizuri Y, Niimi M, Uehara Y. 2007. Inhibition of fungal $\mathrm{ABC}$ transporters by unnarmicin $\mathrm{A}$ and unnarmicin $\mathrm{C}$, novel cyclic peptides from marine bacterium. Biochemical and Biophysical Research Communications 364. DOI: 10.1016/j.bbrc.2007.10.110.

Tang SS, Prodhan ZH, Biswas SK, Le CF, Sekaran SD. 2018. Antimicrobial peptides from different plant sources: Isolation, characterisation, and purification. Phytochemistry 154. DOI: 10.1016/j.phytochem.2018.07.002.

Tiwari S, Jamal SB, Hassan SS, Carvalho PVSD, Almeida S, Barh D, Ghosh P, Silva A, Castro TLP, Azevedo V. 2017. Two-component signal transduction systems of pathogenic bacteria as targets for antimicrobial therapy: An overview. Frontiers in Microbiology 8. DOI: 10.3389/fmicb.2017.01878.

Tornesello AL, Buonaguro L, Tornesello ML, Buonaguro FM. 2018. The Role of Sensing Peptides in the Cross-talk between Microbiota and Human Cancer Cells. Mini-Reviews in Medicinal Chemistry 18. DOI: 10.2174/1389557518666180713112119.

Totsika M. 2016. Benefits and Challenges of Antivirulence Antimicrobials at the Dawn of the Post-Antibiotic Era. Drug Delivery Letters 6. DOI: 10.2174/2210303106666160506120057.

Tsai CN, MacNair CR, Cao MPT, Perry JN, Magolan J, Brown ED, Coombes BK. 2020. Targeting Two-Component Systems Uncovers a Small-Molecule Inhibitor of Salmonella

Peer) reviewing PDF | (2021:10:67017:1:0:NEW 29 Nov 2021) 
731

732

733

734

735

736

737

738

739

740

741

742

743

744

745

746

747

748

749

750

751

752

753

754

755

756

757

758

759

760

761

762

763

764

765

766

767

768

Virulence. Cell Chemical Biology 27. DOI: 10.1016/j.chembiol.2020.04.005.

Vasilchenko AS, Rogozhin EA. 2019. Sub-inhibitory effects of antimicrobial peptides. Frontiers in Microbiology 10. DOI: 10.3389/fmicb.2019.01160.

Wang H yan, Lin L, Tan L si, Yu HY, Cheng JW, Pan Y ping. 2017. Molecular pathways underlying inhibitory effect of antimicrobial peptide Nal-P-113 on bacteria biofilms formation of Porphyromonas gingivalis W83 by DNA microarray. BMC Microbiology 17. DOI: 10.1186/s12866-017-0948-z.

Wang W, Mulakala C, Ward SC, Jung G, Luong H, Pham D, Waring AJ, Kaznessis Y, Lu W, Bradley KA, Lehrer RI. 2006. Retrocyclins kill bacilli and germinating spores of Bacillus anthracis and inactivate anthrax lethal toxin. Journal of Biological Chemistry 281. DOI: 10.1074/jbc.M603614200.

Yajima A. 2016. Recent Advances in the Chemistry and Chemical Biology of Quorum-Sensing Pheromones and Microbial Hormones. In: Studies in Natural Products Chemistry. DOI: 10.1016/B978-0-444-63603-4.00010-3.

Yang G, Cheng H, Liu C, Xue Y, Gao Y, Liu N, Gao B, Wang D, Li S, Shen B, Shao N. 2003. Inhibition of Staphylococcus aureus pathogenesis in vitro and in vivo by RAP-binding peptides. Peptides 24. DOI: 10.1016/j.peptides.2003.09.017.

Zapotoczna M, Forde É, Hogan S, Humphreys H, O'gara JP, Fitzgerald-Hughes D, Devocelle M, O’Neill E. 2017. Eradication of staphylococcus aureus biofilm infections using synthetic antimicrobial peptides. Journal of Infectious Diseases 215. DOI: 10.1093/infdis/jix062.

Zasloff M. 2019. Antimicrobial peptides of multicellular organisms: My perspective. In: Advances in Experimental Medicine and Biology. DOI: 10.1007/978-981-13-3588-4_1.

Zhang L yu, Fang Z hui, Li Q li, Cao CY. 2019. A tooth-binding antimicrobial peptide to prevent the formation of dental biofilm. Journal of Materials Science: Materials in Medicine 30. DOI: $10.1007 / \mathrm{s} 10856-019-6246-6$.

Zhang Y, Faucher F, Zhang W, Wang S, Neville N, Poole K, Zheng J, Jia Z. 2018. Structureguided disruption of the pseudopilus tip complex inhibits the Type II secretion in Pseudomonas aeruginosa. PLoS Pathogens 14. DOI: 10.1371/journal.ppat.1007343.

Zhang W, Li C. 2016. Exploiting quorum sensing interfering strategies in gram-negative bacteria for the enhancement of environmental applications. Frontiers in Microbiology 6. DOI: 10.3389/fmicb.2015.01535.

Zhu C, Tan H, Cheng T, Shen H, Shao J, Guo Y, Shi S, Zhang X. 2013. Human $\beta$-defensin 3 inhibits antibiotic-resistant Staphylococcus biofilm formation. Journal of Surgical Research 183. DOI: $10.1016 /$ j.jss.2012.11.048.

Table 1. Main peptides and polypeptides with anti-virulence and adjuvant properties

\begin{tabular}{|l|l|l|l|l|}
\hline \multicolumn{1}{|c|}{ Name } & \multicolumn{1}{|c|}{ Source } & \multicolumn{1}{c|}{ Activity } & \multicolumn{1}{c|}{ Effect } & \multicolumn{1}{c|}{ References } \\
\hline $\begin{array}{l}\text { PI peptide } \\
\text { (Derived from } \\
\text { polyphemusin I) }\end{array}$ & $\begin{array}{l}\text { Horseshoe } \\
\text { crab }\end{array}$ & $\begin{array}{l}\text { Anti- } \\
\text { biofilm }\end{array}$ & $\begin{array}{l}\text { Inhibits the development of biofilm of } \\
\text { S. mutans in the dental plaque of rabbit } \\
\text { incisors. }\end{array}$ & $\begin{array}{l}\text { Zhang et al., } \\
2019\end{array}$ \\
\hline
\end{tabular}




\begin{tabular}{|c|c|c|c|c|}
\hline Hepcidin 20 & $\begin{array}{l}\text { Derived } \\
\text { from human } \\
\text { liver }\end{array}$ & $\begin{array}{l}\text { Anti- } \\
\text { biofilm }\end{array}$ & $\begin{array}{l}\text { Inhibit the production and } \\
\text { accumulation of extracellular matrix in } \\
\text { the biofilm of } S \text {. epidermidis. }\end{array}$ & $\begin{array}{l}\text { Brancatisano et } \\
\text { al., } 2014\end{array}$ \\
\hline $\begin{array}{l}\text { AMP complex } \\
\text { (defensin, cecropin, } \\
\text { diptericin and } \\
\text { proline rich peptide } \\
\text { families) }\end{array}$ & $\begin{array}{l}\text { Calliphora } \\
\text { vicina } \\
\text { worms }\end{array}$ & $\begin{array}{l}\text { Anti- } \\
\text { biofilm }\end{array}$ & $\begin{array}{l}\text { Destroys the matrix and cells of the } \\
\text { biofilm of E. coli, } S \text {. aureus, and } A \text {. } \\
\text { baumannii. }\end{array}$ & $\begin{array}{l}\text { Gordya et al., } \\
2017\end{array}$ \\
\hline $\begin{array}{l}\text { S4 (1-16) } \\
\text { M4Ka } \\
\text { (Dermaseptin S4 } \\
\text { derivative) }\end{array}$ & $\begin{array}{l}\text { Amphibian } \\
\text { skin }\end{array}$ & $\begin{array}{l}\text { Anti- } \\
\text { biofilm }\end{array}$ & $\begin{array}{l}\text { Destroys immature } P . \text { fluorescens } \\
\text { biofilms. }\end{array}$ & $\begin{array}{l}\text { Quilès et al., } \\
2016\end{array}$ \\
\hline $\begin{array}{l}\text { Piscidin- } \\
3 /\left(\mathrm{Cu}^{2+}\right)\end{array}$ & Fish & $\begin{array}{l}\text { Anti- } \\
\text { biofilm }\end{array}$ & $\begin{array}{l}\text { Damages } E \text {. coli DNA in a copper- } \\
\text { dependent manner. }\end{array}$ & $\begin{array}{l}\text { Libardo et al., } \\
2017\end{array}$ \\
\hline$\beta$-defensin 3 & Humans & & $\begin{array}{l}\text { Decreases the formation of biofilms in } \\
\text { Staphylococcus, as well as the } \\
\text { expression of genes responsible for its } \\
\text { production. }\end{array}$ & Zhu et al., 2013 \\
\hline $\begin{array}{l}\text { LL-37 } \\
\text { (Derived from } \\
\text { cathelicidin) }\end{array}$ & Humans & $\begin{array}{l}\text { Anti- } \\
\text { biofilm, } \\
\text { anti-QS }\end{array}$ & $\begin{array}{l}\text { Reduces the expression of the Las and } \\
\text { RhI genes. Inhibits the biofilm } \\
\text { formation in P. aeruginosa, F. } \\
\text { novicida, S. epidermidis, and S. aureus. }\end{array}$ & $\begin{array}{l}\text { Hancock \& } \\
\text { Sahl, 2006; } \\
\text { Overhale et al } \\
\text { 2008; } \\
\text { Chennupati et } \\
\text { al., 2009; } \\
\text { (Amer, Bishop } \\
\text { \& van Hoek, } \\
\text { 2010; Hell et } \\
\text { al., 2010; Kang, } \\
\text { Dietz \& Li, } \\
\text { 2019. } \\
\end{array}$ \\
\hline $\begin{array}{l}\text { LIVRHK and } \\
\text { LIVRRK }\end{array}$ & Synthetics & $\begin{array}{l}\text { Anti-QS, } \\
\text { anti-biofilm }\end{array}$ & $\begin{array}{l}\text { They inhibit biofilm formation and the } \\
\text { production of virulence factors } \\
\text { (pyocyanin, protease, and } \\
\text { rhamnolipids) in P. aeruginosa. Also, } \\
\text { they reduce the expression of lasI, lasR, } \\
\text { rhlI, and rhlR. }\end{array}$ & $\begin{array}{l}\text { Taha et al., } \\
2019\end{array}$ \\
\hline Peptide 1037 & Synthetic & $\begin{array}{l}\text { Anti- } \\
\text { biofilm }\end{array}$ & $\begin{array}{l}\text { Inhibits the formation of biofilms of } P \text {. } \\
\text { aeruginosa, B. cenocepacia, and } L \text {. } \\
\text { monocytogenes. Also, it reduces the } \\
\text { expression of a variety of genes } \\
\text { involved in its formation. }\end{array}$ & $\begin{array}{l}\text { de la Fuente } \\
\text { Nuñez et al., } \\
2012\end{array}$ \\
\hline D-Bac $8 c^{2,5 L e u}$ & Synthetic & $\begin{array}{l}\text { Anti- } \\
\text { biofilm }\end{array}$ & $\begin{array}{l}\text { Prevents the formation of } S \text {. aureus } \\
\text { biofilms on catheters. }\end{array}$ & $\begin{array}{l}\text { Zapotoczna et } \\
\text { al., } 2017\end{array}$ \\
\hline
\end{tabular}




\begin{tabular}{|c|c|c|c|c|}
\hline Bovicin HC5 & $\begin{array}{l}\text { Streptococc } \\
\text { us bovis } \\
\text { HC5 }\end{array}$ & \multirow[t]{2}{*}{$\begin{array}{l}\text { Anti- } \\
\text { biofilm, } \\
\text { anti-QS }\end{array}$} & \multirow[t]{2}{*}{$\begin{array}{l}\text { Reduces the formation of biofilms in } S \text {. } \\
\text { aureus. }\end{array}$} & \multirow[t]{2}{*}{$\begin{array}{l}\text { Pimentel-Filho } \\
\text { Nde et al., } 2014\end{array}$} \\
\hline Nisin & $\begin{array}{l}\text { Lactococcus } \\
\text { lactis }\end{array}$ & & & \\
\hline Subtilosin & $\begin{array}{l}\text { Bacillus } \\
\text { subtilis } \\
\text { KATMIRA } \\
1933\end{array}$ & $\begin{array}{l}\text { Anti- } \\
\text { biofilm, } \\
\text { anti-QS }\end{array}$ & $\begin{array}{l}\text { Reduces the production of violacein in } \\
\text { C. violaceum. Also, biofilm formation } \\
\text { and AI-2 production in } G \text {. vaginalis. }\end{array}$ & $\begin{array}{l}\text { Algburi et al., } \\
2017\end{array}$ \\
\hline RBP15 & Synthetic & Anti-QS & $\begin{array}{l}\text { Inhibits the phosphorylation of the } \\
\text { RNAIII activator protein (TRAP) in } S \text {. } \\
\text { aureus. }\end{array}$ & $\begin{array}{l}\text { Yang et al., } \\
2003\end{array}$ \\
\hline $\begin{array}{l}\text { P1(EWESDN } \\
\text { RLNEEQ) and } \\
\text { P2 } \\
\text { (TKLTRTWR } \\
\text { Q) }\end{array}$ & Synthetic & Anti-T2SS & $\begin{array}{l}\text { They disrupt the XcpVW pseudopilin } \\
\text { nucleus complex and the tip of the } \\
\text { pseudopilus. Inhibit T2SS and reduce } \\
\text { the virulence of P. aeruginosa in the } \\
\text { Caenorhabditis elegans model. }\end{array}$ & $\begin{array}{l}\text { Zhang et al., } \\
2018\end{array}$ \\
\hline Lactoferrin & Mammals & Anti-T3SS & $\begin{array}{l}\text { Inhibit T3SS in Salmonella, Shigella, } \\
\text { and } E . \text { coli through the degradation of } \\
\text { translocon proteins. }\end{array}$ & $\begin{array}{l}\text { McShan \& De } \\
\text { Guzman, } 2015\end{array}$ \\
\hline $\begin{array}{l}\text { CoilA, Coil B } \\
\text { and CesA2 }\end{array}$ & Synthetic & Anti-T3SS & $\begin{array}{l}\text { Inhibit the formation of the T3SS } \\
\text { needle in EPEC and reduce hemolysis. }\end{array}$ & $\begin{array}{l}\text { Larzábal et al., } \\
2019\end{array}$ \\
\hline HNP, HD5 & Human & Anti-toxin & $\begin{array}{l}\text { Inhibit the Lethal Factor of } B . \\
\text { anthracis, diphtheria toxin, exotoxin } \mathrm{A} \\
\text { of } P \text {. aeruginosa and cytotoxin } \mathrm{B} \text { of } C \text {. } \\
\text { difficile. }\end{array}$ & $\begin{array}{l}\text { Kim et al 2005, } \\
2006 \text {; } \\
\text { Giesemann et } \\
\text { al., 2008; }\end{array}$ \\
\hline $\mathrm{hBD}$ & Human & Anti-toxin & $\begin{array}{l}\text { Inhibits the gonococcal toxin NarE of } \\
N . \text { gonorrhoeae and the Lethal Factor } \\
\text { of B. anthracis. }\end{array}$ & $\begin{array}{l}\text { Rodas et al., } \\
\text { 2016; Wei et al., } \\
2009\end{array}$ \\
\hline Retrocyclins & Human & Anti-toxin & $\begin{array}{l}\text { Inhibit the Lethal factor of } B . \text { anthracis } \\
\text { and the vaginolysin of } G \text {. vaginalis. }\end{array}$ & $\begin{array}{l}\text { Wang et al., } \\
\text { 2006; Hooven et } \\
\text { al., } 2012\end{array}$ \\
\hline Bacitracin & $\begin{array}{l}\text { Bacillus } \\
\text { subtilis }\end{array}$ & Anti-toxin & $\begin{array}{l}\text { They inhibit various toxins such as } \\
\text { Lethal Factor (B. anthracis), C2 toxin } \\
\text { (C. botulinum), CDT transferase ( } C \text {. } \\
\text { difficile), and epsilon toxin ( } C \text {. } \\
\text { perfringens). }\end{array}$ & $\begin{array}{l}\text { Schnell et al., } \\
2019\end{array}$ \\
\hline Histatin 5 & Human & Anti-toxin & $\begin{array}{l}\text { Inhibits the exoproteases of } P \text {. } \\
\text { gingivalis involved in the generation }\end{array}$ & $\begin{array}{l}\text { Gusman et al., } \\
\text { 2001; Le, Fang }\end{array}$ \\
\hline
\end{tabular}




\begin{tabular}{|l|l|l|l|l|}
\hline & & & $\begin{array}{l}\text { of damage in periodontal disease and } \\
\text { the cysteine proteinases of } C . \\
\text { histolyticum. }\end{array}$ & $\begin{array}{l}\text { \& Sekaran, } \\
2017\end{array}$ \\
\hline $\begin{array}{l}\text { Unarmycin A } \\
\text { and C }\end{array}$ & $\begin{array}{l}\text { Marine } \\
\text { bacteria }\end{array}$ & Adjuvants & $\begin{array}{l}\text { Inhibit the azole antifungal efflux } \\
\text { pumps and restore antifungal } \\
\text { sensitivity in C. albicans. }\end{array}$ & $\begin{array}{l}\text { Tanabe et al., } \\
2007\end{array}$ \\
\hline $\begin{array}{l}\text { Plantaricin } \\
\text { PLNC8 } \alpha \beta\end{array}$ & $\begin{array}{l}\text { Lactobacill } \\
\text { plantarum }\end{array}$ & Adjuvants & $\begin{array}{l}\text { Enhances the activity of conventional } \\
\text { antibiotics against Staphylococcus } \\
\text { strains. }\end{array}$ & $\begin{array}{l}\text { Bengtsson et al., } \\
2020\end{array}$ \\
\hline
\end{tabular}

769

770

771

772

773

774

775

776

777

778

779

780

781

782

783

784

785

786

787

788

789

790

791

792

793

T3SS = type 3 secretion system; T2SS = type 2 secretion system; $\mathbf{Q S}$ = quorum sensing; EPEC = enteropathogenic $E$. coli.

\section{Figure legends}

Figure 1. Antibacterial properties of antimicrobial peptides (AMP). The bactericidal properties are one of the main characteristics of AMP, its lytic capacity being one of the beststudied mechanisms of action. However, other targets have been identified in which they act as nucleic acids, proteins, or the divisome machinery. Unfortunately, as with other bactericidal agents, they also induce resistance. When AMPs work at sub-inhibitory concentrations, they exhibit anti-virulence properties, reducing the production of various factors that cause damage, but without affecting the viability of the bacteria. One of the targets is the inhibition of quorum sensing (QS), a general virulence regulator.

Furthermore, AMPs inhibit bacterial secretion systems, inactivate toxins, and exhibit adjuvant properties, restoring the activity of antibiotics on resistant strains. In the anti-biofilm activity, AMPs can act by bactericidal mechanisms or anti-virulence by inhibiting QS. An ideal property for anti-virulence therapies is that they do not generate resistance or are expected to do so to a lesser degree. $\mathrm{MIC}=$ minimum inhibitory concentration.

\section{Figure 2. Proposal for peptide role at sub-MIC concentrations in microbial populations.}

Gram-positive bacteria produce autoinducer peptides for bacterial communication by quorum sensing. These can interfere with eukaryotic cells and induce adverse or beneficial effects. In the same way, cells can generate peptides as an immunogenic response to combat pathogenic microorganisms (AMPs or anti-virulence). Anti-virulence peptides can also be produced as a 
794 competition strategy within microbial populations. A particular microbial population does not 795 produce inducer peptides, but they alter their gene expression. The effect of these peptides seems 796 to be random and a consequence of the peptides that circulate within the complex

797 communication network. In turn, signal peptides allow a bacterial population to perceive when 798 microenvironmental conditions are adequate or inappropriate and generate a reaction. These can 799 favor the establishment or dispersal of populations.

800

801 


\section{Figure 1}

Figure 1

Figure 1. Antibacterial properties of antimicrobial peptides (AMP). The bactericidal properties are one of the main characteristics of AMP, its lytic capacity being one of the beststudied mechanisms of action. However, other targets have been identified in which they act as nucleic acids, proteins, or the divisome machinery. Unfortunately, as with other bactericidal agents, they also induce resistance. When AMPs work at sub-inhibitory concentrations, they exhibit anti-virulence properties, reducing the production of various factors that cause damage, but without affecting the viability of the bacteria. One of the targets is the inhibition of quorum sensing (QS), a general regulator of virulence. Furthermore, AMPs inhibit bacterial secretion systems, inactivate toxins, and exhibit adjuvant properties, restoring the activity of antibiotics on resistant strains. In the anti-biofilm activity, AMPs can act by bactericidal mechanisms or anti-virulence by inhibiting QS. An ideal property for anti-virulence therapies is that they do not generate resistance or are expected to do so to a lesser degree. MIC = minimum inhibitory concentration. 


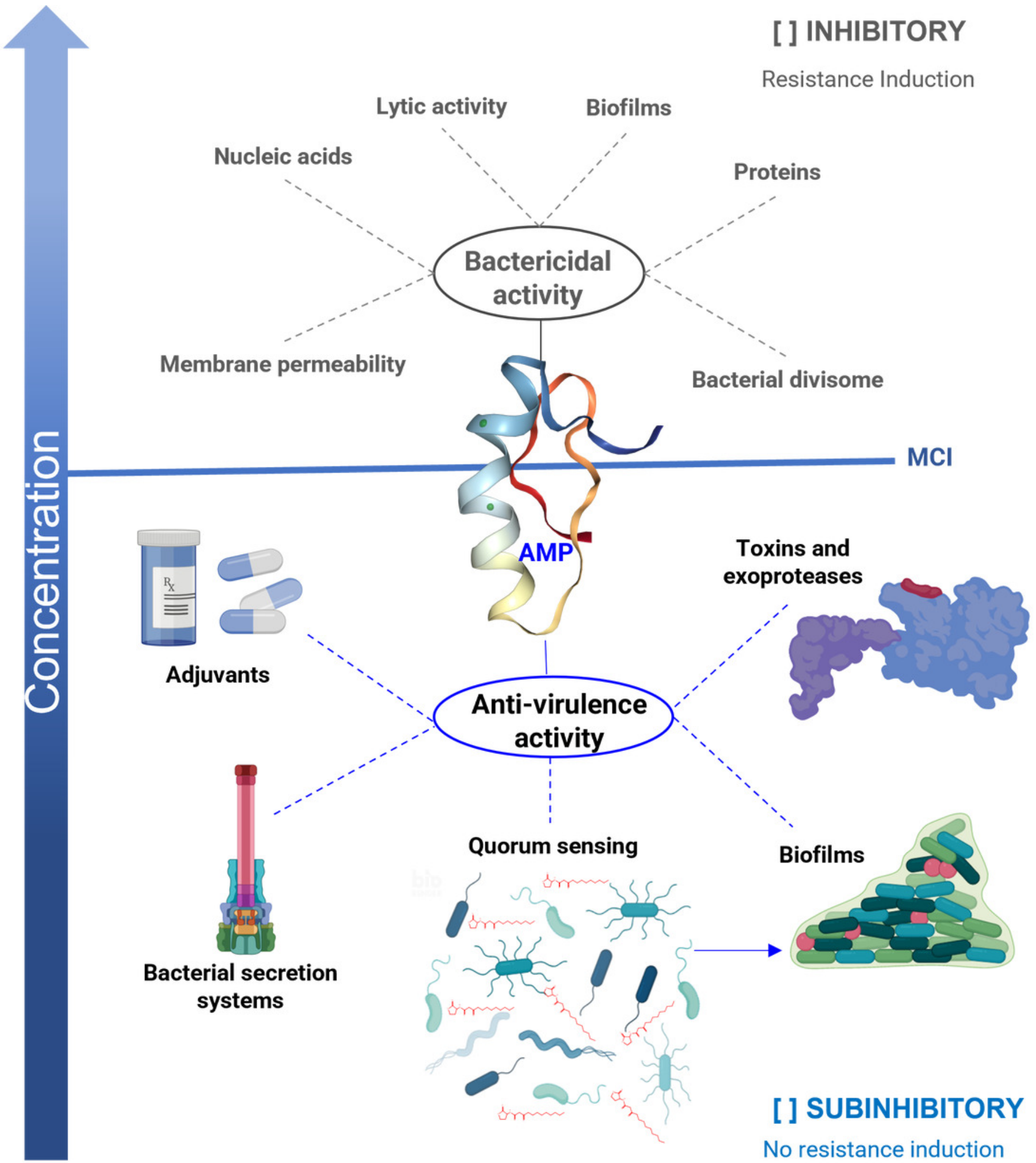




\section{Figure 2}

Figure 2

\section{Figure 2. Proposal for peptide role at sub-MIC concentrations in microbial}

populations. Gram-positive bacteria produce autoinducer peptides for bacterial communication by quorum sensing. These can interfere with eukaryotic cells and induce adverse or beneficial effects. In the same way, cells can generate peptides as an immunogenic response to combat pathogenic microorganisms (AMPs or anti-virulence). Antivirulence peptides can also be produced as a competition strategy within microbial populations. A particular microbial population does not produce inducer peptides, but they manage to alter their gene expression. The effect of these peptides seems to be random and a consequence of the peptides that circulate within the complex communication network. In turn, signal peptides allow a bacterial population to perceive when microenvironmental conditions are adequate or inappropriate and generate a reaction. These can favor the establishment or dispersal of populations. 


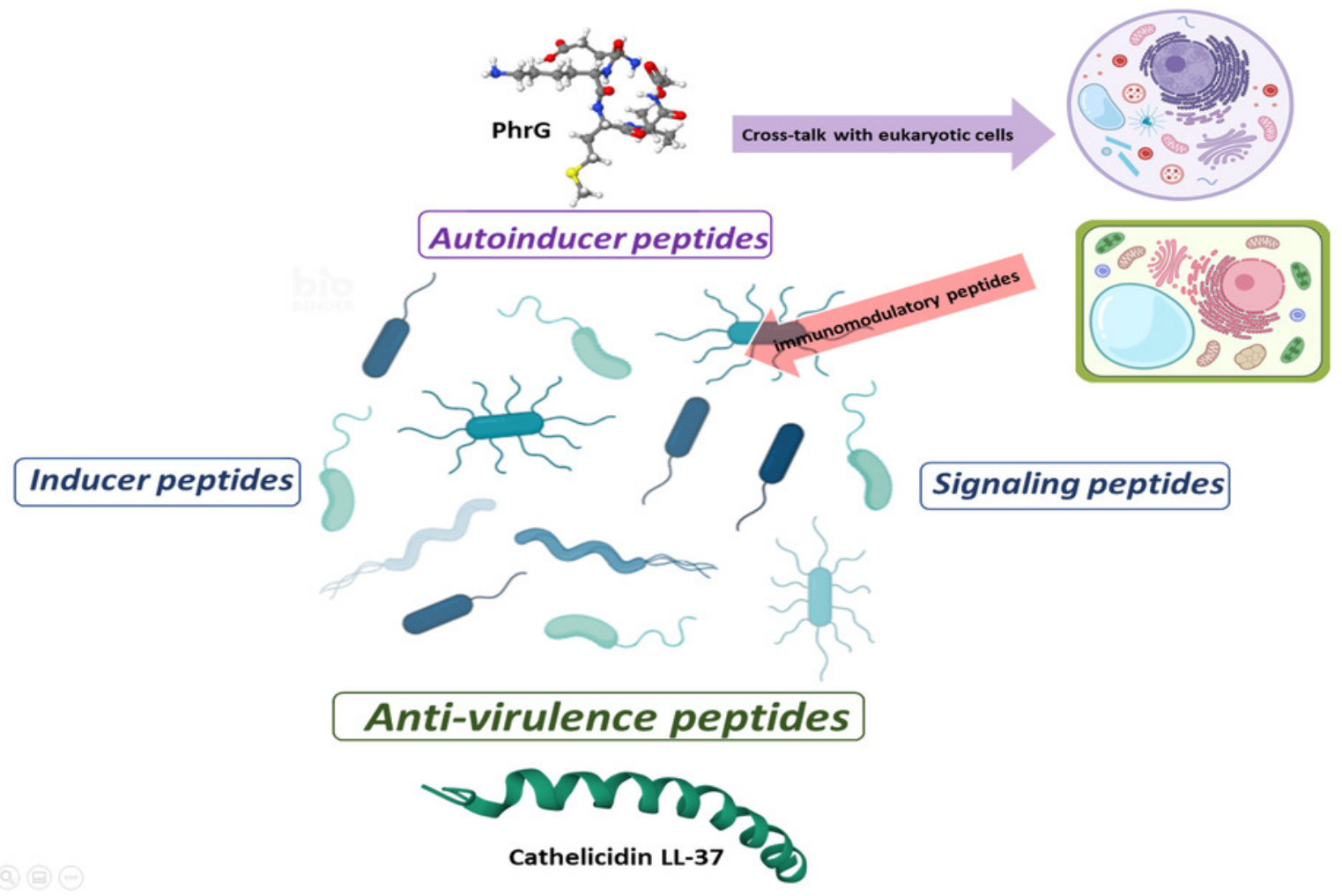

